\title{
Contributions on the interplay between technology, culture and development
}

\begin{abstract}
Book Title:
From technology transfer to intercultural development
\end{abstract}

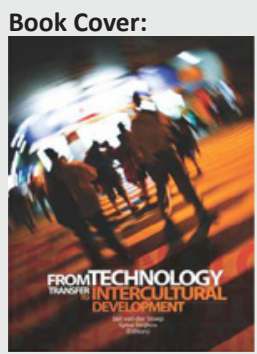

Editors:

Jan van der Stoep Sytse Strijbos

ISBN:

978-1-920383-28-2

(South Africa)

Publisher:

Sun Media

(Bloemfontein 2012)

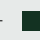

Review Title:

Contributions on the

interplay between

technology, culture and

development

Reviewer:

G.P. van Rheede van

Oudtshoorn ${ }^{1}$

\section{Affiliation:}

${ }^{1}$ School of Communication

Studies, North-West

University, South Africa

Email:

21067775@nwu.ac.za

Postal address:

Private Bag X6001,

Potchefstroom 2520,

South Africa

How to cite this book review:

Van Rheede van

Oudtshoorn, G.P., 2012,

'Contributions on the

interplay between technology,

culture and development',

Koers - Bulletin for Christian

Scholarship 77(2), Art. \#429,

2 pages. $h t t p: / / d x . d o i$.

org/10.4102/koers.v77i2.429

(C) 2012. The Authors.

Licensee: AOSIS

OpenJournals. This work

is licensed under the

Creative Commons

Attribution License.
From technology transfer to intercultural development is a collection of views from scholars and practitioners that dwell on the topics of technology, interculturalism, religion, development and health-related studies. The collection is compiled in two parts: Part One focuses on six empirical studies loosely related to the broad theme of the book, and Part Two includes four theoretical reflections on 'intercultural development'. The aim of the book is to explore and comment on the role of cultures and worldviews in the development of technology. The common point of departure (or more academically stated, the interdisciplinary conceptual framework) for the authors is how they view technology, which is, simply put, that technological advancements should serve the common good of all people and cultures.

Four of the six chapters in Part One are based on the South African context, with the other two providing global perspectives. The four chapters address, respectively, the experiences and perspectives of residents of low-cost houses and how a sense of unity addresses fear; development projects that incorporate modern technology, and how the inclusion of the role of culture can provide a richer understanding of the complexity of intercultural interaction; communitybased HIV support for potentially beneficial interventions, such as voluntary HIV counselling and testing, originating in the developed world; and how biomedical technology can benefit traditional communities, if introduced in a way that respects the societies' cultural identity. The other two chapters address how a global company adapts operations to the ethical standards present in a local environment (a valuable contribution to the debates on 'glocalisation'), and an analysis of the current debate on global security, military practice and possible alliances with development practice.

The first chapter of Part Two is a revised version of an article published in 1998 and offers a view on the role of technology in modernisation theory and world system theory. The second chapter explores the religious roots of information technology and -systems; whilst the third provides the reader with an idea of what is meant by intercultural development. The last chapter offers interesting perspectives on religion and development, drawing inferences from the synthesis between religion, human development and several authoritative figures.

The value of this compilation of perspectives lies within its discussion on how to blend technology, technological advancements and technical solutions into the collective mind-set and social structure of a community. It does provide critique on the modernisation paradigm in so far as it acknowledges the asymmetrical nature of it. Technology, one gets the idea, is far more useful and stronger as a development factor if it is selected, used, discussed and adapted in conjunction and collaboration with the targeted community. The authors base their studies and comments on the move away from development aid towards development cooperation.

The merit of the publication is that it contributes to a discussion of technological advancement or development in general. It touches on cultural interaction in the use and role of technology in society in varying degrees. The reader should be aware that the chapters of the book are compiled thematically according to technology and development and that each chapter has its own unique focus.

The book does not succeed in fully exploring what it means by intercultural development, and how each of the chapters contributes towards such a concept. Although the penultimate chapter explicates the notion of intercultural development, the book would have gained value if the other chapters also reflected on it. Intercultural development is a hot topic and can provide an exciting debate. It would have been interesting if the other chapters provided a stronger analysis thereof in contribution to the reasoning that surrounds it.

Those interested in technological development, specifically the acceptance of communities or cultures of technological development, and how culture fulfils some or other role in discussions thereof, will find this book valuable. 
The point of departure of the book is very general. The reader is left with a need for a stronger golden thread throughout the publication. Yet, as a collection of perspectives, the book does offer a contribution.

The basic points of departure focus on current perspectives of development, but show a lack of depth in terms of recent perspectives on social change. The idea of the developed world developing the non-developed world is not simply accepted and receives deserved critique. There is, however, room for improvement in terms of the depth of critique. The ideas of participation, dialogue and symmetry in intercultural exchanges and social change warrant stronger inclusion and elaboration.

The last two chapters of the book provide the backbone of the publication. Perhaps the reader should do the sensible thing and start by reading these two chapters first! 